\title{
FORESTRY COMMISSIONS IN CANADA ${ }^{1}$
}

\author{
By J. D. B. HARRISON 2
}

I feel that the Canadian Institute of Forestry is to be congratulated on its choice of theme - Forestry Commissions in Canada - for this, its 50th annual meeting. For reasons of soil and climate, Canada is and always will be peculiarly dependent upon its forests as a source of employment and new wealth. Our forests have already contributed much to our well-being; they are one of the mainstays of our export trade and purchasing power in other countries, but they are by no means fully developed as yet. As we all know, the forest is a renewable resource but it is also destructible. Since proper management is essential if we are to preserve and improve the productivity of forests now in use, and since there still remain considerable areas of productive forest to be brought into use in the future, it is essential to the national well-being that future forest development should be guided by wise policies. Policy has been the special concern of Royal Commissions.

Technically, a Royal Commission is a body appointed by the Crown to inquire into, report upon, and make recommendations concerning a given problem. In practice, it is a convenient device whereby a democraticallyelected government, no member of which may have specialized knowledge of the problem at issue, can provide for a thorough examination of a question by experts and profit by their recommendations in formulating legislation. During the past 15 years this device has been resorted to by governments in Canada, with respect to forestry problems, with remarkable frequency. The findings of these particular commissions have been highly constructive, but it must be admitted that there have been occasions when Royal Commissions dealing with other subjects have not aroused too much enthusiasm. The well-known humorist and parliamentarian, Sir Alan Herbert, is quoted by Professor Dawson as follows:

"The necessity for action was clear to everyone,

But the view was very general that nothing could be done,

And the Government courageously decided that the Crown

Should appoint a score of gentlemen to track the trouble down -

Which always takes a long, long time."

Sir Alan's generality certainly does not apply to Canadian Royal Commissions on Forestry since most, if not all of them, completed their labors within two years - a short enough period when one considers the scope of the problems they were asked to study and the variety of interested parties whose views they were bound to learn and to take into consideration. Furthermore, none of these commissions numbered anything approaching his "score of gentlemen". In three provinces the responsibility was entrusted to a sole commissioner.

\footnotetext{
"Theme address, 50th Annual Meeting of the Canadian Institute of Forestry held in Fredericton, N.B., October 5-9, 1958.

- Director, Forestry Branch, Department of Northern Affairs and National Resources, Ottawa, Ontario.
} 
Before considering further the functions of Canadian Forestry Commissions, it would be well to list those that have sat during the last fifteen years. In 1944 the report of the Royal Commission on Provincial Development and Rehabilitation for Nova Scotia, of which Professor R. MacGregor Dawson was sole Commissioner, included recommendations on forestry. The first commission to publish a report after the termination of World War II was the Royal Commission on Forestry of British Columbia, of which the Honourable Gordon MacGregor Sloan was the sole Commissioner. This report appeared in 1945. The same distinguished gentleman conducted a second commission ten years later and reported in 1957. The Royal Commission on Forestry of Ontario, of which Major-General Howard Kennedy was sole Commissioner, reported in 1947, and in the same year a report was published by the Royal Commission on Forestry of Saskatchewan, of which Mr. Frank Eliason was Chairman. In 1955 there appeared the Report of the Royal Commission on Forestry of Newfoundland, of which Major-General Kennedy was Chairman. In 1957 the Report of the New Brunswick Forest Development Commission (Dr. John S. Bates, Chairman) was published and also in that year appeared the Report of the Forestry Study Group of the Commission on Canada's Economic Prospects headed by Mr. W. L. Gordon. The last-mentioned Commission was not specifically a commission on forestry but the report I have just mentioned is, nevertheless, a document of importance to the development of forestry policy in this country. In 1958 a report was published by the Royal Commission on the Development of Northern Alberta, of which Mr. J. G. McGregor was Chairman. Here again this Commission was not concerned solely with forestry but it did make significant findings with respect to forest resource possibilities in the northern half of that province.

The list I have just read shows that forestry has been considered by Royal Commissions in seven provinces, and for the Dominion as a whole, during the last fifteen years. This fact by itself is remarkable evidence of widespread and sustained interest in the development of sound forest policies, and to it must be added the progress that has been made in developing forest policies, during the same period, by those provinces which have not used the commission technique.

It seems important at this stage to inquire as to whether there is any common foundation or principle upon which the forest policy recommendations of these various commissions are based. A review of the reports makes it very clear that the answer to that question is in the affirmative. All these commissions have labored to ensure that the forest resources should be wisely used in the best interests of the community as a whole, including both present and future generations. This is the Conservation Principle.

Here I would like to suggest that Conservation should always be thought of in the sense in which I have just used it, namely, as a principle on which resource policies ought to be based. These policies, whether they are concerned with forests or with other resources, must in effect provide for action and from the moment this action is taken we are entering the field of sound resource management rather than resource conservation. It seems to me that there has been a good deal of fruitless discussion about the establishment of 
so-called conservation principles when what was really under consideration was methods of resource management. Conservation is itself the great principle which should be common to all policies governing the use of natural resources. On the other hand, there is a well-established body of doctrine and technique which has been developed for the management of each resource.

Water power is not managed in the same way as mines, nor is there much similarity between the management of wildlife and farmland. Forest management has its own problems, determined by the nature of the forest, the industries it supports, and the other benefits it can yield. The function of all these commissions has been to promote sound management of the forest in accordance with the Conservation Principle.

An editorial in a recent issue of The Forestry Chronicle concludes with these words:

"If the Fredericton meeting, on the C. I. F.'s 50th birthday as a national body, can provide for the exchange of experience on the use of forestry commissions to build forest policy, then it has every likelihood of making a major contribution to Canadian forestry."

I most heartily agree and I have already pointed out that the chief function of these commissions has been to recommend improvements in forest policy. They have also made important recommendations regarding the best means for putting such policies into execution.

Action with respect to a natural resource must be taken by those who own it. Canada is a federation and the forests belonging to the Crown and lying within the boundaries of any province are under the control of the provincial, rather than the national, government. This situation is defined by the British North America Act. Under the circumstances the policies governing the administration of the great majority of Canadian forests are and will continue to be policies of the various provincial governments. This does not mean that the Dominion Government should not have a policy with respect to forestry and, indeed, it has one.

Apart from the various statutes under which federal Crown lands are administered, the forest policy of the Dominion Government is made effective chiefly under the authority of the Canada Forestry Act (1949), supplemented by the work of the Forest Biology Division of the Science Service of the Department of Agriculture. Although there is no formal statement of this policy, it can be summarized as follows:

(1) To administer forests under the direct control of the Dominion Government in accordance with sound forestry principles;

(2) To conduct research in forestry and in the utilization of forest products and to make the results of that research available to provincial governments and to forest industries; and

(3) To provide financial assistance to the provinces with respect to specified forestry activities.

This policy of the Dominion Government is based on recognition of the fact of provincial ownership of most of Canada's forests on the one hand, 
and on recognition of the great and real national interest in the welfare of the forests and the industries dependent on them, on the other.

When one examines the forestry legislation and administrative regulations of the ten provinces of Canada, it is possible to find considerable differences between them, but, on the whole, the similarities are far more striking than the differences. Perhaps some of these differences give rise to difficulties for industrial companies which operate in more than one province, and some of them may even have unfavorable effects on the development of better forest management. However, the commission approach to the development of improved policies, and the publication of commission findings and recommendations which all may read, may prove to be a fruitful means for securing greater uniformity than now exists. It seems abundantly clear that all Canadian forestry authorities are striving towards the same end, and there is every reason to hope that the best solutions to specific problems will eventually secure widespread acceptance, wherever they may originate.

In conclusion, I would like to stress the conviction that we are nowhere close to full utilization of the potential productivity of Canada's forests, nor are we in sight of ultimate limitations upon further expansion of our forest industries. If we are to reap the full benefits of the forest resources with which we have been so richly endowed, we must steadily continue to develop still better policies and procedures suitable to the conditions peculiar to the various regions of our country. Experience to date suggests that forestry commissions established by governments provide a most useful instrument for ensuring progress, and one may close with the hope that the present meeting may lead toward still fuller realization of the potentialities of the commission approach to forestry problems. 